\title{
Absence of Localizing Auto-antibodies in Serum Obtained from Tumor (Yoshida Sarcoma) Bearing Rats and Tumor Resistant Rats
}

\author{
By \\ Hajime Sugiyama and Takeo Kuroyanagi \\ From the Third Department of Internal Medicine, Faculty of Medicine, \\ University of Tokyo, Tokyo; Director: Prof. K. Nakao
}

(Received for publication, April 14, 1965)

\begin{abstract}
It is still undetermined whether tumor bearing animals produce humoral anti-tumor auto-antibodies or not. The difference of opinions about the presence of humoral anti-tumor auto-antibodies seems likely to be due to the absence of a reliable and reproducible method to detect anti-tumor auto. antibodies.

The ${ }^{131} \mathrm{I}$ labeled antibody technique was employed in this study to detect anti-Yoshida sarcoma cell auto-antibodies in rats with subcutaneous solid Yoshida sarcoma and in rats which survived intraperitoneal injections of Yoshida sarcoma cells.

Neither sarcoma cell agglutinins nor tumor localizing auto-antibodies were demonstrated in serum of rats with subcutaneous solid Yoshida sarcoma and in rats which survived intraperitoneal innoculations of Yoshida sarcoma cells.
\end{abstract}

The presence of humoral anti-tumor auto-antibodies in serum of tumor bearing animals has not still been established. The difference of opinion about the presence of humoral anti-tumor auto-antibodies seems likely to be based on the absence of a reliable and reproducible method to detect anti-tumor auto-antibodies.

The ${ }^{131}$ I labeled antibody technique ${ }^{1-4}$ is one of the most reliable methods for the detection of anti-tumor antibodies. The antibody demonstrated by this method represents the localizing antibody produced against saline insoluble antigens of tumors and is identical with the cytotoxic antibody.

It has been well known that some rats which received intraperitoneal transplantations of Yoshida sarcoma cells survive without developing ascitic sarcoma and become resistant to the retransplantation of them. This fact suggests that the immunologic response plays some roles in the mechanism of the rejection of tumor transplantation. However, the exact mechanism of tumor rejection still remains to be clarified.

杉山 始, 畔節武雄 
Thus we undertook to determine anti-tumor localizing auto-antibodies in serum of rats which survived transplantations of Yoshida sarcoma cells, by means of the ${ }^{131} \mathrm{I}$ labeled antibody technique.

\section{METHODS}

1. simental animals

order to get rats which survive the transplantation of Yoshida sarcoma cells, vommercial albino rats of mixed breed were inoculated intraperitoneally with ascitic Yoshida sarcoma cells. The rats which survived the transplantation of Yoshida sarcoma cells received subcutaneous injection of sarcoma cells 2-3 months after the first transplantation. None of them developed solid Yoshida sarcoma tumor. They were sacrificed to obtain serum 10 days after the retransplantation.

These sera will be called as sera of tumor resistant rats, hereafter.

Rats of mixed breed were also innoculated subcutaneously with Yoshida sarcoma cells. They were sacrificed to obtain serum ten days after transplantations of sarcoma cells. These sera will be called as sera of tumor bearing rats.

\section{Fractionation of globulin}

Globulin was obtained by adding slowly to 1 volume of serum at room temperature 2 volumes of stock sodium sulfate solution ( $27 \mathrm{~g} \mathrm{Na}_{2} \mathrm{SO}_{4}$ per $100 \mathrm{ml}$ solution, brought to $\mathrm{pH} 8$ with porate). The crude globulin precipitate was centrifuged down, washed once with a sodium sulfate solution containing 2 volumes of stock and 1 volume of porate buffer $(\mathrm{pH} 8)$, redissolved in 0.5 volume buffer, reprecipitated with 0.5 volume stock sodium sulfate, and taken up in a minimum of 0.9 per cent $\mathrm{NaCl}$ (brought to $\mathrm{pH} 8$ with borate). The final product was dialyzed twice against 12 liters portions of the borate buffered saline, cleared by centrifugation, lyophilized and stored at $5^{\circ} \mathrm{C}$.

\section{Radioiodination}

The method described by Pressman was used with slight modifications. ${ }^{5}$

Reagents were $1.0 \mathrm{~N} \mathrm{HCl}, 1.0 \mathrm{~N} \mathrm{NaOH}, 0.002 \mathrm{M} \mathrm{KI}, 0.02 \mathrm{M} \mathrm{NaNO}_{2}$ and $\mathrm{pH}$ 8 borate buffer.

The following cold solutions were prepared: (A) $1.0 \mathrm{ml}, 1.0 \mathrm{~N} \mathrm{HCl}, 0.25 \mathrm{ml}$ $0.002 \mathrm{M} \mathrm{KI}$ containing $200 \mu \mathrm{C}^{131} \mathrm{I}$, (B) $1.0 \mathrm{ml}, 1.0 \mathrm{~N} \mathrm{NaOH}, 5 \mathrm{ml}$ borate buffer ( $\mathrm{pH}$ 8). In rapid succession, $0.2 \mathrm{ml}$ of $0.02 \mathrm{M} \mathrm{NaNO}_{2}$ was mixed in solution (A), followed by solution (B). The resultant solution was then added with thorough and rapid mixing to solution $(\mathrm{C})$. The mixture was dialized at $5^{\circ} \mathrm{C}$ against two successive 12 liters quantities of borate buffered saline to remove unbound iodide.

4. Assay for localization of ${ }^{131}$ I labeled globulin

Donryu rats weighing 120 to $180 \mathrm{~g}$ were innoculated in the back of flank region 
subcutaneously with ascitic Yoshida sarcoma cells. Seven days after implantation of sarcoma cells, they were examined on the size of solid Yoshida sarcoma tumors. Rats bearing tumor of the similar sized were selected to determine the in vivo localization of ${ }^{131} \mathrm{I}$ labeled globulins. ${ }^{131} \mathrm{I}$ labeled globulins were injected into tail vein of above tumor bearing Donryu rats. Forty-eight hours after injections rats were weighed, heparinized and perfused with physiologic saline. Tissue samples weighing less than $1.0 \mathrm{~g}$ were used for the determination of radioactivity. Usually the kidney and the spleen were counted as a whole, whereas the liver and the tumor was counted as a piece meal. An uneven distribution of radioactivities in tumor was necessiated to count the whole tumor.

Radioactivities was determined using the well type scintillation counter.

The total radioactivities localized in each organ is the sum of specific localization of radio-labeled localizing antibodies and non-specific localization of radiolabeled normal globulins. The percentage localization of ${ }^{131} I$ labeled normal rat globulins (background localization) was considered to represent the non-specific localization. The specific localization (net localization) was determined by calculating the differences between the observed total localization of ${ }^{131} \mathrm{I}$ labeled antiglobulin and background localization. The net localization below the background localization for the particular tissues was considered to indicate the absence of localizing antibody. Mean value of percentage localization which was determined in five rats was considered to represent the percentage localization of each globulin sample.

\section{Agglutination test}

The determination of sarcoma cell agglutinin titer in serum of normal, tumor resistant and tumor bearing rats was carried out by following method.

i) Preparation of Yoshida sarcoma cell suspension

The ascitic fluid obtained from rats with Yoshida sarcoma was centrifuged to obtain the sarcoma cells. The sarcoma cells were washed with physiologic saline containing 1/10 volume of $1 \%$ EDTA and suspended in it. The suspensions had 10,000 to 20,000 sarcoma cells per $\mathrm{cmm}$.

The sera to be tested were inactivated at $56^{\circ} \mathrm{C}$ for 30 minutes and set up in serial dilutions in physiologic saline from $1: 1$ to $1: 1024$.

One-tenth $\mathrm{ml}$ portions of sarcoma cell suspensions were added to $0.1 \mathrm{ml}$ of each dilution of test serum. After one hour of incubation at $37^{\circ} \mathrm{C}$, one drop of $1 \%$ acetic acid was added to each tube to hemolyse the red cells. Each tube was then vigorously tapped against a hard surface about 20 times. Aliquots of each suspension were coverslipped on clear glass slides and examined for the agglutination microscopically. Normal serum control was included with each test. All procedures were carried out in siliconized glassware. 


\section{RESULTS}

\section{Difference of the percentage localization according to the tumor weight}

The percentage localization of ${ }^{131}$ I labeled normal rat globulins were determined in Donryu rats bearing tumors of various weight.

As shown in Table I, the percentage localization in the tumor showed a marked variation according to the weight of tumors.

Generally speaking, the percentage localization in rats bearing a small tumor was less than that in rats bearing a large tumor.

The percentage localization in tumors of similar weights showed the similar values. Thus it may be concluded that it is necessary to use rats bearing tumors of approximately similar weights in the studies on the tumor localizing antibody.

Tabre I. Differences of Percentage Localization of 131I

Labeled Normal Globulins in Solid Yoshida Sarcoma

Tumors According to Their Weight

\begin{tabular}{c|c}
\hline $\begin{array}{c}\text { Weight of tumors } \\
(\mathrm{g})\end{array}$ & $\begin{array}{c}\% \\
(\%)\end{array}$ \\
\hline 1.0 & 1.2 \\
1.0 & 1.0 \\
1.5 & 1.0 \\
1.5 & 1.2 \\
2.0 & 1.2 \\
2.0 & 1.4 \\
2.0 & 1.3 \\
2.5 & 1.6 \\
2.5 & 1.6 \\
3.0 & 1.6 \\
3.0 & 1.6 \\
3.0 & 1.7 \\
3.0 & 1.8 \\
3.5 & 2.4 \\
3.5 & 2.3 \\
3.5 & 2.5
\end{tabular}

\section{Absence of localizing antibody in serum of tumor bearing rats}

${ }^{131}$ I labeled globulins of tumor bearing rats were injected into Donryu rats with solid Yoshida sarcoma tumors of approximately similar size and the percentage localization in various organs was calculated.

As shown in Table II, the percentage localization of 131 labeled normal rat globulins in the tumor, liver, kidney and spleen of Donryu rats with solid Yoshida sarcoma tumors more than $3 \mathrm{~g}$ averaged $2.3,0.8,0.1 \%$ and $0.1 \%$, respectively. The percentage of radioactivity localized per one gram (wet weight) of tissues averaged as follows:

$1.0 \%$ in the tumor, $0.2 \%$ in the liver, $0.1 \%$ in the kidney and $0.4 \%$ in the spleen. 
TABLE II. Percentage Localization of ${ }^{131}$ L Labeled Globulin of Tumor Bearing Rats

\begin{tabular}{|c|c|c|c|c|c|c|c|c|c|}
\hline \multirow{2}{*}{$\begin{array}{l}\text { Tumor } \\
\text { weight }\end{array}$} & \multirow{2}{*}{ Globulin } & \multicolumn{2}{|c|}{ Tumor } & \multicolumn{2}{|c|}{ Liver } & \multicolumn{2}{|c|}{ Spleen } & \multicolumn{2}{|c|}{ Kidney } \\
\hline & & Total & per $g$ & Total & per $g$ & Total & per $\mathrm{g}$ & Total & per $g$ \\
\hline \multirow[b]{2}{*}{$3 \mathrm{~g}$} & Normal & 1.2 & 0.8 & 0.6 & 0.1 & 0.1 & 0.2 & 0.1 & 0.1 \\
\hline & $\begin{array}{c}\text { Globulin of } \\
\text { tumor bearing } \\
\text { rats }\end{array}$ & 1.2 & 0.8 & 0.7 & 0.2 & 0.1 & 0.2 & 0.1 & 0.1 \\
\hline \multirow[b]{2}{*}{$3 \mathrm{~g}$} & Normal & 2.3 & 1.0 & 0.8 & 0.2 & 0.1 & 0.4 & 0.1 & 0.1 \\
\hline & $\begin{array}{l}\text { Globulin of } \\
\text { tumor bearing } \\
\text { rats }\end{array}$ & 2.4 & 1.1 & 0.7 & 0.2 & 0.1 & 0.4 & 0.2 & 0.1 \\
\hline
\end{tabular}

Notes : Total : Per cent of total radioactivities localized to injected dose

Per g : Per cent of radioactivities of one gram of tissues to injected dose

The percentage localization of ${ }^{131} \mathrm{I}$ labled globulins of tumor bearing rats in the tumor, liver, kindey and spleen averaged $2.4,0.7,0.1 \%$ and $0.2 \%$, respectively in Donryu rats with solid Yoshida sarcoma tumors more than $3 \mathrm{~g}$. The percentage localization per one gram of tissues was $1.1 \%$ in the tumor, $0.2 \%$ in the liver, $0.1 \%$ in the kidney and $0.4 \%$ in the spleen.

The in vivo localization of ${ }^{131} \mathrm{I}$ labeled normal globulins in Donryu rats bearing solid Yoshida sarcoma tumors was less than $3 \mathrm{~g}$ as follows:

$1.2 \%$ in the tumor, $0.6 \%$ in the liver, $0.1 \%$ in the kidney and $0.1 \%$ in the spleen. The percentage localization per one gram of tissues in the tumor, liver, kidney and spleen averaged $0.8 \%, 0.1 \%, 0.1 \%$ and $0.2 \%$, respectively.

The in vivo localization of ${ }^{131} \mathrm{I}$ labeled globulins of tumor bearing rats in the tumor, liver, kidney and spleen averaged $1.2,0.7,0.1 \%$ and $0.1 \%$, respectively in Donryu with solid Yoshida sarcoma tumors was less than $3 \mathrm{~g}$. The percentage localization per $1 \mathrm{~g}$ of tissues averaged as follows:

0.8 in tumor, $0.2 \%$ in liver, $0.1 \%$ in kidney and $0.2 \%$ in spleen.

\section{Absence of localizing auto-antibody in serum of tumor resistant rats}

The percentage localization of ${ }^{131} \mathrm{I}$ labeled globulins of tumor resistant rats in the tumor, liver, kidney and spleen averaged $1.0,0.6,0.1 \%$ and $0.2 \%$, respectively.

Table III. Percentage Localization of ${ }^{131} \mathrm{I}$ Labe]ed Globulins of Tumor Resistant Rats

\begin{tabular}{l|c|c|c|c|c|c|c|c}
\hline & \multicolumn{2}{|c|}{ Tumor } & \multicolumn{2}{c|}{ Liver } & \multicolumn{2}{c|}{ Spleen } & \multicolumn{2}{c}{ Kidney } \\
\cline { 2 - 8 } & Total & perg & Total & per g & Total & per g & Total & perg \\
\hline Normal globulin & 1.2 & 0.8 & 0.6 & 0.1 & 0.1 & 0.2 & 0.1 & 0.1 \\
\hline $\begin{array}{l}\text { Globulins of tumor } \\
\text { resistant rat }\end{array}$ & 1.0 & 0.9 & 0.6 & 0.1 & 0.2 & 0.4 & 0.1 & 0.1
\end{tabular}


The percentage localization per one gram of tissues averaged $0.9 \%$ in the tumor, $0.1 \%$ in liver, $0.1 \%$ in kidney and $0.4 \%$ in spleen (Table III).

\section{Agglutination test}

As shown in Table IV, no agglutinins were demonstrated in both sera of tumor resistant rats and of tumor bearing rats.

Table IV. Absence of Sarcoma Cell Agglutinins in Serum of Tumor Bearing and Tumor Resistant Rats

\begin{tabular}{l|c|c|c|c|c|c|c|c|c|c|c|c}
\hline & $1: 2^{0}$ & $1: 2^{3}$ & $1: 2^{2}$ & $1: 2^{3}$ & $1: 2^{4}$ & $1: 2^{5}$ & $1: 2^{6}$ & $1: 2^{7}$ & $1: 2^{8}$ & $1: 2^{9}$ & $1: 2^{10}$ & $1: 2^{11}$ \\
\hline $\begin{array}{l}\text { Serum of tumor } \\
\text { bearing rats }\end{array}$ & - & - & - & - & - & - & - & - & - & - & - & - \\
\hline $\begin{array}{l}\text { Serum of tumor } \\
\text { resistant rats }\end{array}$ & - & - & - & - & - & - & - & - & - & - & - & - \\
\hline
\end{tabular}

\section{COMMENTS}

Until recently accumulated evidences suggesting the presence of tumor specific antigen have been reported. Many investigators could produce heterologous antitumor antibodies showing cross reaction with normal tissues, ${ }^{6-12}$ by means of injecting tumor homogenates into animals of other species.

However, the production of anti-tumor auto-antibodies in tumor bearing individuals still remains to be determined. Harrington ${ }^{13}$ has reported that the vaccination of autologous leukemic cells with Freund's adjuvant produced a remission in chronic myelocytic leukemia. This fact suggests the possibility of production of auto-antibody against malignant neoplasma in patients.

Takeda could demonstrate the presence of sarcoma cell agglutinins in serum of Yoshida sarcoma rats, suggesting the production of auto-antibody against sarcoma cells. However, many other investigators failed to demonstrate any antitumor auto-antibodies in tumor bearing animals.

It has been well established that rats which survived intraperitoneal transplantations of Yoshida sarcoma cells reject retransplanted sarcoma cells.

According to Akiyama, ${ }^{14} \mathrm{C} 3 \mathrm{H} / \mathrm{He}$ mice which were transplanted with $\mathrm{MH} 134$ tumor cells died within 40 days. However, $\mathrm{C} 3 \mathrm{H} / \mathrm{He}$ mice which were injected with spleen cells of dd strain mice which survived transplantation of MH 34 tumor cells, survived against innoculations of MH 134 tumor cells. These facts suggest that immunologic reactions might play some roles in the mechanism of tumor rejection.

Therefore, an experiment was undertaken to study the presence of antitumor localizing auto-antibodies in tumor bearing rats and tumor resistant rats, by means of ${ }^{131}$ labeled antibody technique. 
The injection of ${ }^{131} \mathrm{I}$ labeled normal globulins into solid Yoshida sarcoma tumor bearing Donryu rats resulted in a great divergence of total localization in tumor. The total percentage localization in large tumors was higher than that in small tumors. When the tumor weights were approximately equal, the percentage localization in tumors showed every similar values.

Thus it may be concluded that it is absolutely necessary to use animals bearing tumors of similar weight in the determination of tumor localizing antibody.

The injection of ${ }^{131} \mathrm{I}$ labeled globulins of tumor bearing rats in the Donryu rat with solid Yoshida sarcoma did not result in their specific localization in the tumor, indicating absence of tumor localizing auto-antibody.

The sera of rats which survived the first intraperitoneal innoculations of ascitic Yoshida sarcoma cells and received subcutaneous reinjection of sarcoma cells without developing solid tumor were pooled. ${ }^{131} \mathrm{I}$ labeled globulins prepared from the above sera was injected into Donryu rats with solid Yoshida sarcoma tumors and their percentage localization in tumors was determined. No differences were observed between the percentage localization of the above globulins and that of normal globulins, indicating the absence of tumor localizing auto-antibodies in serum of tumor resistant rats.

The agglutination test carried on the sera obtained from tumor bearing and tumor resistant rats demonstrated no agglutinins in them.

The above results indicate that rats with Yoshida sracoma do not produce any circulating anti-tumor auto-antibodies.

However, it may be possible that some cellular auto-antibodies may be responsible for the tumor rejection. ${ }^{15}$ The role of cellular auto-antibody in tumor immunity is now under experiments.

\section{Acknowledgment} Nakao.

We thank for the kind guidance of Emeritus Prof. S. Okinaka and Prof. K.

\section{References}

1) Korngold, L. \& Pressman, D. Cancer Res., 1954, 14, 96.

2) Day, E.D. Planisek. J. A., Korngold, L. \& Pressman. D. J. nat. Cancer Inst., 1965, 17, 517 .

3) Day, E.D. \& Pressman, D. Ann. N.Y. Acad. Sci., 1957, 69, 651.

4) Day, E.D., Barnes, G.W., Planisek, J.A. \& Pressman, D. J. nat. Cancer Inst., $1958,20,1123$.

5) Kuroyanagi, T., Kurisu, A. \& Sugiyama, H. Blood, 1963, 21, 594.

6) Okubo, S., in GanSaibo no Kogensei (Jap.) (Antigenicity of Cancer Cells), edited by Takeda, K, Nanzando, Tokyo, 1957, p. 119.

7) Green H., Fleisher, R.A., Barrow, R. \& Goldberg, B. J. exp. Med., 1959, 109, 505. 111, 109.

8) Day, E.D. Ann. Rev. Biochem., 1962, 31, 549.

9) Amos, D.B. \& Stetson, C.A. Ann. N.Y. Acad. Sci., 1962, 101, 1. 
10) Hirai, H., Taga, H. \& Warabioka, K. J. Biochem. (Tokyo), 1964, 55, 178.

11) Hirai, H. Jap. J. clin. Sci. (Jap.), 1965, 1, 96.

12) Kuroyanagi, T. \& Sugiyama, H. Tohoku J. exp. Med., 1964, 82, 224.

13) Harrington. W.J., Halloran, M.J., Kricheff, V., White, B. \& Scheibe, R. IX Intern. Congress of Hematology, 1962.

14) Akiyama, T., Maeda, K. \& Nakao, T. Keio Igaku (Jap.), 1963, 40, 311.

15) Hanaoka, M. Acta haemat. jap., 1964, 27, 155. 